\title{
The prevalence of antibodies to Hepatitis B core antigen among blood donors in a tertiary institution in Nairobi County, Kenya
}

\author{
Festus Mulakoli ${ }^{\mathrm{a}^{*}}$, Michael Gichure ${ }^{\mathrm{a}}$ \\ aDepartment of Zoological Science, Kenyatta University, Nairobi, Kenya \\ *Correspondence to Mr. Festus Mulakoli (mulakolifesto@gmail.com)
}

\begin{abstract}
Background: Infections linked to blood transfusion or tissue transplants prove to be a major challenge globally because of the serological window period (WP) and a latent stage exhibited by most viral infections. The objective of this study was to determine the prevalence of anti-HBc antibodies in HBsAg negative donors at Aga Khan University Hospital Nairobi.

Methods: The current project was a cross-sectional study in which 76 donor samples that tested negative for HBsAg marker were reevaluated with an anti-HBc ELIA kit (Elecsys reagent kit) following Cobas 601(Roche, Stuttgart, Germany) machine operation manual. Anti-HBc positive samples were confirmed for positivity using polymerase chain reaction (PCR). Donor demography and risk factors such as age; gender, marital status, employment status, and donor type were reviewed and documented from the archived questionnaires.

Results: In total, 76 archived samples were screened during the period of the study. The study population had an average age of $32 \pm 8$ years which male donors dominating at $n=61(79.2 \%)$ and female $n=16(20.8 \%)$. The prevalence rate of anti-HBc Total was $13 \%$ during the period of the study. On further analysis of the 10 anti-HBc positive samples with PCR, there was no detectable HBV-DNA. The majority $(63.6 \%)$ of Anti-HBc positive cases were first-time donors and blood donors aged between 25-45 years being the majority.

Conclusions: The introduction of anti-HBc as a routine screening tool is recommended to all potential blood donors and even in other medical procedures such as dialysis. These support the need for a duo approach when screening potential donors to rule out occult infection.
\end{abstract}

Key words: Antibodies, Hepatitis B virus, anti-Hepatitis B core total, Transfusion, Blood donor, Window period

\section{INTRODUCTION}

$\Gamma$ ransfusion of blood and tissue transplants is one of the

channels in which disease causing pathogens to get transmitted to the blood or tissue recipients if the donors were not screened for infectious diseases ${ }^{1}$. Hepatitis $B$ virus infection is characterized by the detection of $\mathrm{HBV}$ DNA, anti-HBc, anti-HBs, and HBsAg among other seromarkers, while seronegative is described by undetectability of both HBV-DNA, anti-HBc, HBsAg and anti-HBs ${ }^{2}$. Hepatitis B surface antigen ( $\mathrm{HBsAg}$ ) was the first marker introduced for the purpose of screening donor tissues for HBV infection since the early 1970s and is currently in use in most blood banks to date. Eventually, this sows a reduction in the number of post-transfusion HBV infection after a blood transfusion or tissue transplant ${ }^{3}$.
Infections associated with blood transfusion or tissue transplant is still a global challenge in transfusion science and organ transplant ${ }^{4,5}$. Different modalities have been put in place all over the world to minimize the risk of transfusion-transmitted infections (TTIs) ${ }^{6}$. Some of these modalities include the use of voluntary blood donation, coming up with donor recruitment guidelines, incorporation of the quality control program in blood donor screening, and minimize blood usage by requesting clinicians ${ }^{7}$.

A prevalence of $5.4 \%$ anti-HBc $(\operatorname{IgM})$ for instance was reported from donors with undetectable levels of $\mathrm{HBsAg}$ negative blood donors in a remote region of Nigeria posing a higher risk to blood recipients ${ }^{8}$. Immunoglobulins to hepatitis $\mathrm{B}$ virus core antigen (IgM) are detectable in individuals with acute hepatitis B virus (HBV) infection or with reactivation of disease in chronic carriers 9 . Total 
hepatitis B core antibodies (anti-HBc IgM and IgG) immunoglobulins, on the other hand, are detected in chronic HBV infection, individuals with the previous exposure, or in the acute stage of the infection ${ }^{10}$. A systematic review from various countries has shown that in 2017, about 1.1 million people were newly infected with chronic HBV infection globally ${ }^{11,12}$. This review reported a bigger difference in the total estimates of HBV prevalence across countries; this in itself explains the difference in risk levels and mode of transmission HBV across continents. Prevalence estimated at a regional level indicated a significant burden of infection in most of the Africa countries and some countries in the Western Pacific region in particular. These reviews highlighted a continuous need for prevention strategies on HBV transmission ${ }^{13,14}$.

The hepatitis B virus and hepatitis $\mathrm{C}$ virus are the leading cause of infectious diseases that leads to higher mortality and morbidity in many communities, draining families financially and destroy economies of most countries which therefore has become a major global health burden ${ }^{15}$. In SubSaharan Africa for instance, $12.5 \%$ of recipients who receive blood transfusion are at greater risk of post-transfusion hepatitis infection ${ }^{16,17}$. In Kenya and other Sub Saharan Africa (SSA) countries, blood donated is screened for HIV 1 and 2, syphilis, Malaria parasite, hepatitis C virus (HCV) and HBV alone ${ }^{18}$. The only intervention to the prevention of transmission of HBV infection and other infectious diseases during blood transfusion is through blood screening ${ }^{19}$. Several scientific publications have reported the existence of $\mathrm{HBV}$ infection in individuals who tested negative for HBsAg but having a detectable amount of HBV virion in their hepatic cells or blood circulation ${ }^{20-24}$. Some of these publications have reported $\mathrm{HBV}$ infections as a result of transfusion of blood screened and found to be HBsAg negative ${ }^{25,26}$. There is strong evidence that HBsAg-negative blood donation still poses a risk of inducing posttransfusional hepatitis in recipients ${ }^{27,28}$. With this uncertainty of HBV screening in mind, the purpose of this study was to determine the prevalence of seropositivity of anti-HBc among healthy Kenyan blood donors and highlight its risk in blood transfusion.

\section{METHODS}

\section{Study area}

The study was carried out in Nairobi County (Figure 1) at the Aga Khan University teaching hospital (AKUHN), Parklands Sub County. Aga Khan University Hospital, Nairobi is a private not-for-profit teaching hospital that provides tertiary and secondary level healthcare services to the vast population of Nairobi County. The University Hospital has been providing high-quality care for the people of East Africa and beyond for several years now. The laboratory has a transfusion service that includes a blood bank and apheresis. In this laboratory, blood is routinely screened for malaria, syphilis, $\mathrm{HBV}, \mathrm{HCV}$, and HIV. screening of $\mathrm{HBV}$ is routinely done by using $\mathrm{HBsAg}$ assay on the Architect 1000SR. Any positive results are then confirmed on the Roche Cobas e601 (Roche, Stuttgart, Germany). Any discrepant result between the two HBsAg assays is considered indeterminate. All pints with a positive or indeterminate result for any of the TTIs screened are usually discarded.

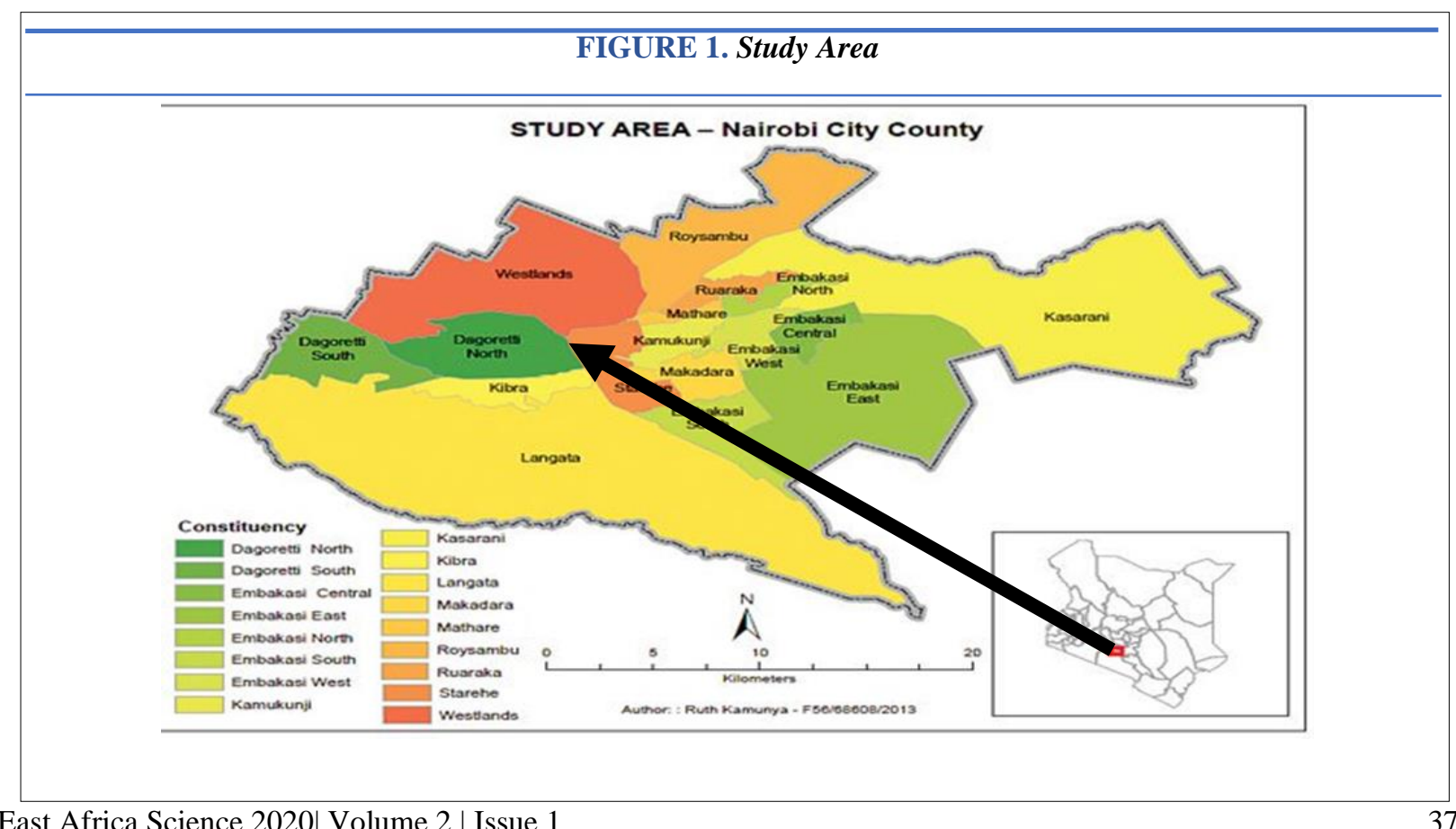

East Africa Science 2020| Volume 2 | Issue 1 
Study design

This was a laboratory-based cross-sectional study (Figure 2) design, where all serum samples screened for HBsAg during the initial blood testing of respective donors at the Aga Khan University hospital Nairobi donor unit were re-analyzed using anti-HBc Total as a marker for HBV. All samples that screened positive for Anti-HBc, plasma samples were obtained and aliquoted and were further screened by Polymerase Chain Reaction (PCR) to confirm anti-HBc positivity. Donor demography and risk factors such as age; gender, marital status, employment status, and history of blood transfusion for positive samples were reviewed by examining archived donor questionnaires stored at the donor unit.
Study population, Inclusion and Exclusion criteria

The study population included all archived samples from healthy blood donors that were initially recruited at the Aga Khan university hospital blood transfusion unit. All HBsAg negative samples collected between April 2019 to May 2019 were eligible for the study. On average, the blood bank receives 300 donors per month thus we were able to achieve the desired sample size within the specified period. All HBsAg negative blood archived samples with no signs of deterioration were included in the study. However, samples that were found to be positive for HBsAg and that showed visible deterioration were excluded from this study.
Sample Size

The minimum sample size ( $n=76$ ) was determined using the Cochran formula ${ }^{29}$ required to allow for adequate statistical power: $n=\frac{z^{2} p q}{e^{2}}$

where $\mathrm{z}$ is 1.96 at $95 \%$ confidence interval; $\mathrm{e}^{2}$ the level of desired precision $(0.05)$; $\mathrm{p}$ is prevalence of occult hepatitis $\mathrm{B}$ infection $(0.6 \%)^{30}$; $\mathrm{q}$ is $(1-\mathrm{p})$.

\section{Sampling procedure}

Seventy-seven serum archived samples negative for HBsAg were purposively sampled for three weeks and reanalyzed for hepatitis B virus core immunoglobulins using ELIA kit (Elecsys reagent kit) following Cobas 601(Roche, Stuttgart, Germany) machine operation manual. Plasma samples for 
the positive anti-HBc total were obtained from the respective donor pack, aliquoted in $1.8 \mathrm{ml}$ vials and stored at $-20{ }^{\circ} \mathrm{C}$ till they were analyzed. The corresponding blood questionnaires were retrieved from the blood bank storage archives. Donor demography and risk factors such as age; gender, marital status, employment status, and donor type were reviewed and documented from the archived questionnaires.

\section{Testing for Anti-HBc}

Hepatitis B core antibodies Total were analyzed using a commercial kit (Elecsys, Stuttgart, Germany) by following the manufacturer's instructions for Cobas $601 .{ }^{31}$ At the main laboratory, the samples were allowed to attain room temperature before analysis using the immunoassay technique on Cobas 601(Roche, Stuttgart, Germany) following a written and approved SOP. Before processing, the selected samples were provided with a unique code for easier identification. The results were entered on a laboratory sheet bearing the unique code for the sample. The report was either read reactive for anti-HBc Total or nonreactive for anti-HBc Total.

\section{Ethical consideration}

Because the study was dealing with archived samples no consent was sort from the donors, but an approval was granted by the AKU research ethical Committee (REC)- Ref: 2019/REC-27 (VL).
Data analysis

The data generated was cleaned and entered into an excel worksheet then analyzed using IBM SPSS version 20 (IBM Corporation, New York, USA). Chi-square was applied to determine if there was any association between donor sociodemographic characteristics, exposure to risk factors and antiHBc positivity. Where $p<0.05$ was of statistical significance. The prevalence of HBV was then calculated and expressed in percentage.

\section{RESULTS}

From the beginning of April 2019 to the end of May 2019, 76 we purposively selected blood donor archived samples and reevaluated them see if Total antiHBc was present. The study population had a mean age of $32 \pm 8$ years with the majority of the samples coming from the male donors at $\mathrm{n}=61(79.2 \%)$ and female $\mathrm{n}=16(20.8 \%)$ (Table 1). At the conclusion of the study, the prevalence rate of anti-HBc Total was 10/76 (13\%) (Figure 3). We further analyzed the 10 anti-HBc positive samples with PCR to confirm the seropositivity, there was no detectable HBV-DNA in the positive samples. We also noted that the majority (63.6\%) of Anti-HBc positive cases were mostly first-time blood donors (Table 2) and aged between 25-45 years (Figure 4).

TABLE 1. Socio-demographic characteristics of 76 hepatitis $B$ surface antigen negative blood donors

\begin{tabular}{llll}
\hline Characteristics & & Frequencies (n) & Percentages (\%) \\
\hline Age(years) & $16-24$ yrs. & 12 & 15.6 \\
& $25-45$ yrs. & 58 & 75.3 \\
& $46-55$ yrs. & 6 & 7.8 \\
Sex & $56-65$ yrs. & 1 & 1.3 \\
Marital status & Male & 61 & 79.2 \\
& Female & 16 & 20.8 \\
& Single & 35 & 45.5 \\
Employment & Married & 41 & 53.2 \\
& Widowed & 1 & 1.3 \\
& Self-employed & 54 & 70.1 \\
& Employed & 15 & 19.5 \\
Type of donor & Unemployed & 8 & 10.4 \\
& First time donor & 40 & 51.9 \\
& Repeat Donor & 31 & 40.3 \\
& Regular Donor & 6 & 7.8 \\
\hline
\end{tabular}




\section{FIGURE 3. Prevalence of anti-HBc Total in the study samples}

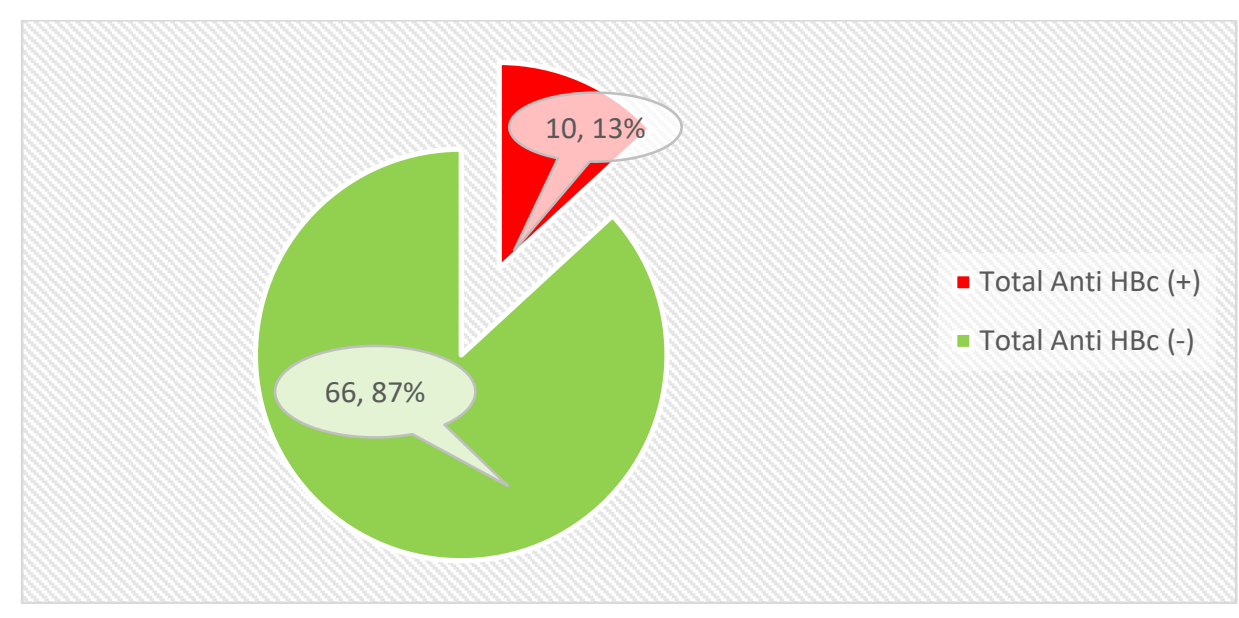

TABLE 2. Socio-demographic characteristics of 76 hepatitis B surface antigen negative blood donors

\begin{tabular}{|c|c|c|c|c|}
\hline Characteristics & Exposed & Not exposed & $\mathbf{X}^{2}$ & P value \\
\hline \multicolumn{5}{|l|}{ Age (years) } \\
\hline $16-24$ & $2(2.6 \%)$ & $10(13.2 \%)$ & 1.294 & 0.731 \\
\hline $25-45$ & $9(11.8 \%)$ & $49(64.5 \%)$ & & \\
\hline $46-55$ & 0 & $6(7.9 \%)$ & & \\
\hline $56-65$ & 0 & $1(1.3 \%)$ & & \\
\hline \multicolumn{5}{|l|}{ Gender } \\
\hline Male & $10(13.1 \%)$ & $51(67.1 \%)$ & 1.065 & $0.301^{* *}$ \\
\hline Female & $1(1.3 \%)$ & $15(19.7 \%)$ & & \\
\hline \multicolumn{5}{|l|}{ Marital status } \\
\hline Single & $6(7.9 \%)$ & $29(38.2 \%)$ & 6.920 & $0.031^{* *}$ \\
\hline Married & $4(5.3 \%)$ & $37(48.7 \%)$ & & \\
\hline Widowed & $1(1.3 \%)$ & 0 & & \\
\hline \multicolumn{5}{|l|}{ Employment } \\
\hline Self-employed & $9(11.8 \%)$ & $45(59.2 \%)$ & 0.982 & 0.612 \\
\hline Employed & $1(1.3 \%)$ & $14(18.4 \%)$ & & \\
\hline Unemployed & $1(1.3 \%)$ & $7(9.2 \%)$ & & \\
\hline
\end{tabular}


Prevalence of Anti-HBc in the Study Population

In total we analyzed $76 \mathrm{HBsAg}$ negative samples on various during the study period. A total of $n=10$ samples were reactive for anti-HBc representing a $13 \%$ prevalence rate (Figure 3). The current picture indicates that apart from the study donors being negative for $\mathrm{HBsAg}$, at one point they had exposure to the hepatitis B virus. These might present a donor with previous exposure or a donor who is recovering from hepatitis B infection. Such information is missed out if a donor is screened for HBsAg alone, a situation that endangers the respective blood recipient. The $87 \%$ represents individuals lacking the two serological markers (that is HBsAg and Total antiHBc), though this in itself does not rule out the existence of other HBV markers especially if the infection is in its initial stages.

Prevalence of Anti-HBc across age groups

The study also sorted to evaluate the distribution of anti-HBc marker among the blood donors. The results described in Figure 4 shows that blood donors between the age of 25 to 45 had the highest reactivity to Total anti-Hbc at $11.7 \%$. The other reactivity was seen between the age of 16-24 years at $2.6 \%$. There were no cases reported in individuals above the age of 46 years.

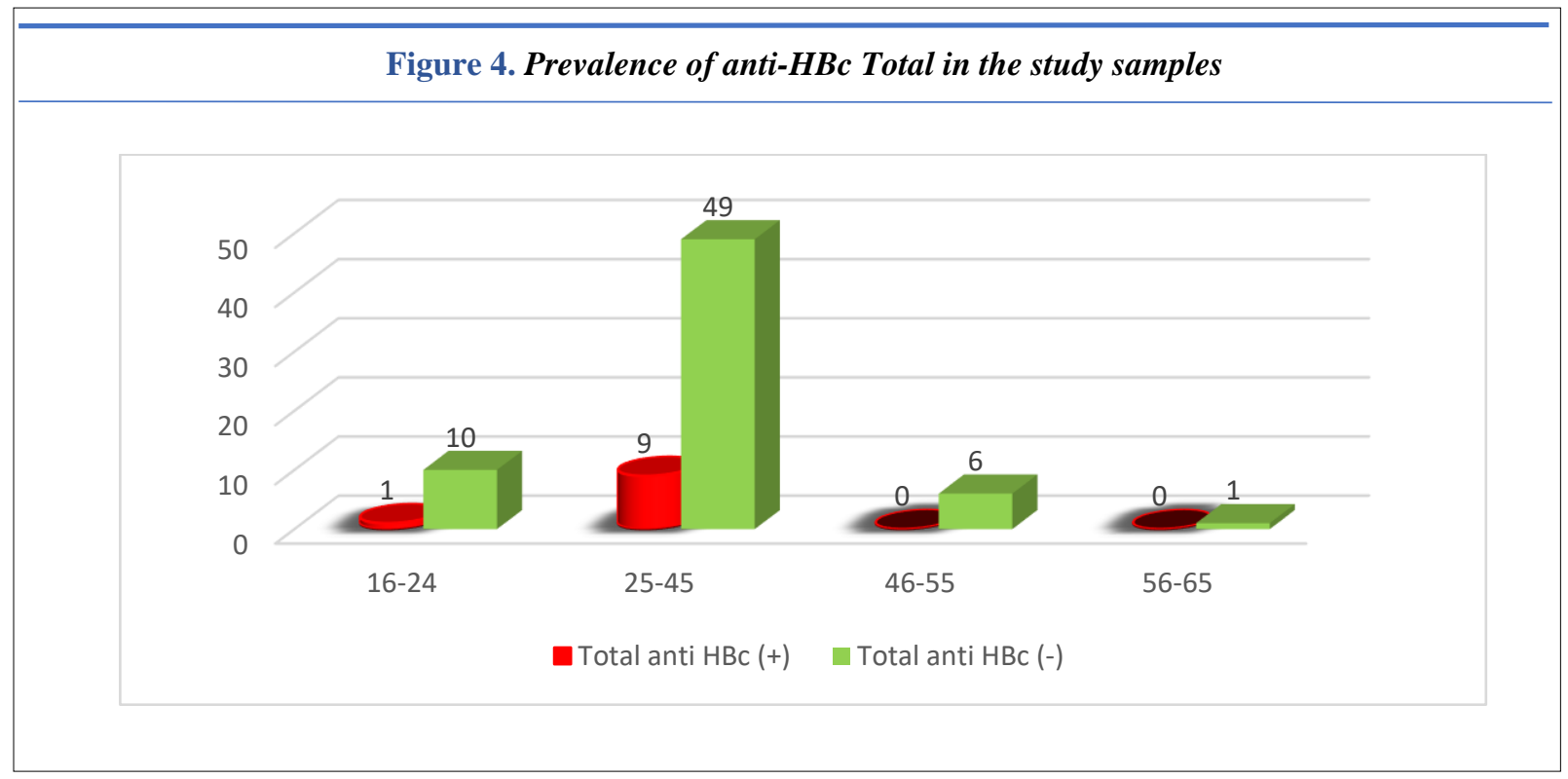

\section{Characteristics of the Selected Archived Samples}

A total of 76 archived samples at Aga Khan University Hospital in Nairobi County were selected into this study. The donor's socio-demographic characteristics are presented below.

\section{Age of the Donors}

The average age of the blood donors selected for the study samples was $32(S D=8$; range $19-71)$ years. There were two age group peaks; of which $75.3 \%$ of the donors were aged 25 to 45 years and $15.6 \%$ were aged between 16 to 24 years. Other age categories included $7.8 \%$ aged between 46 to 55 years $(7.8 \%)$ and aged above 56 years $(1.3 \%)$ being the list aged group (Table 1).

\section{Gender of the Donors}

In the current study, $61(79.2 \%)$ were male donors while less than a quarter of $16(20.8 \%)$ were female donors. Across all age groups, the majority of the participants were males. Among those aged 25-45 years' male was 44 (75.9\%) while females were $14(24.1 \%)$; those aged 16 to 24 years' male were $11(91.7 \%)$ while females were $1(9.3 \%)$. Among those aged 46 - 55 years $(83 ; 69.7 \%)$ were females while $(36$; $30.3 \%$ ) were males. For those aged 41 to 50 years $5(83.3 \%)$ were males while $1(16.7 \%)$ were female. Those aged $\geq 55$ years we had only 1 male as shown in Table 1 .

\section{Occupation and Marital status of the donors}

About $70.1 \%$ of the donors were self-employment, $19.5 \%$ were engaged either in formal or informal employment follow by $10 \%$ donors who were students. Half of the donors $(53.2 \%)$ were married, $45.5 \%$ were single and only $1.3 \%$ widowed. Most of the donors in this study we self-employed and half of them were married (Table 1).

Risk Factors Associated with Occult Among Blood Donors Table 2 summaries the socio-demographic characteristics of selected donors and the risk factors associated with anti-HBc positivity. Most of the donors were males $79.2 \%$ and the female $16 \%\left(\mathrm{X}^{2}=1.065, \mathrm{p}=0.301\right)$. we performed a statistical analysis to see if the was any association between the donor's socio-demographics and anti HBc seropositivity. On performing a Chi-square statistical analysis, there was no significant association between gender and anti-HBc positivity. However, this study showed that the male donors had the highest prevalence rate of $12.1 \%(n=9)$ as compared to female donors with a prevalence rate of $1.3 \%(\mathrm{n}=1)$. 
Around $11.8 \%$ of the anti $\mathrm{HBc}$ Total reactive donors were aged 25 to 45 years versus $1.3 \%$ aged $<24$ years $(p=0.731)$. Donors who were currently single $(7.9 \%)$ were with the highest prevalence of anti-HBc Total, followed by the married donors at $5.3 \%$. There was a significant difference between those who were single and married regarding anti$\mathrm{HBc}$ positivity with a $\mathrm{p}$ value of 0.031 . This was statistically significant, showing a strong association between marital status and anti-HBc reactivity. There was no association between donor's type $(p=0.500)$; age $(p=0.731)$, presence of a tattoo $(\mathrm{p}=0.471)$; occupation $(\mathrm{p}=0.621)$ and anti $\mathrm{HBc}$ positivity.

\section{DISCUSSIONS}

There is an increased risk of blood recipients getting infected with HBV from blood donors if blood screening is not done properly and the existence of occult hepatitis B infection in donors with $\mathrm{HBsAg}$ negative results. Therefore, these results show that the anti-HBc positivity was probably due to previous exposure that had resolved. Blood safety is among the major challenges encountered in blood transfusion practice today. As outlined in most blood transfusion guidelines $\mathrm{HBsAg}$ detection is the number one serological marker utilized for the detection of HBV in most blood transfusion centres in Kenya ${ }^{32}$.The study also revealed that the selected samples were positive for total anti-HBc an indication that the donors had an initial exposure to HBV. However, this finding was found to be higher than the $4 \%$ described by Kisangau et al, in (october 2018) among the health care workers in Makueni county ${ }^{33}$. Similarly, it was also different to a $4.4 \%$ prevalence rate as described in a study by Salawu et al, (2011) in Nigeria for anti-HBc among blood donors ${ }^{34}$. On a global comparison, the current study had a higher prevalence as compared to $6.3 \%$ and $8 \%$ in Saudi Arabia and Iran among potential blood donors respectively ${ }^{35,36}$.

Nonetheless, other studies reported a higher prevalence. For instance, there was a higher prevalence rate of anti-HBc of $16.6 \%$ from Egyptian donors as described by Said et al, (2013). ${ }^{37}$ Similar findings of $10.5 \%$ were reported by Lavanya et al, (2012) in India ${ }^{38}$. The distinguishing factors between this study and other studies that were done in other global regions could be attributed to varying levels of endemicity of HBV infection and differences in societal dynamics across geographical regions ${ }^{39}$. This lower endemicity seen in developed countries could be attributed to various factors which include; the geographical location, cultural practices regarding marriage, the availability of highly sensitive test kits, and stringent donor selection procedures, literacy levels among their population, voluntary donations, and differences in their level of civilization from the study settings ${ }^{40}$. The current study was carried out in a country that is still developing and facing a lot of societal issues that predispose individuals to be more vulnerable to hepatitis B infection.

In Kenya, the seroprevalence of anti-HBc is low as shown from this study in comparison to other African countries, and consequently, screening of donor blood for either anti-HBc
IgM or total anti-HBc may be used in some circumstances especially if there is a historical suspicion of a donor being exposed. However, the lack of HBsAg detection as seen from the current study in itself does not guarantee blood safety because there is evidence of post-transfusion HBV infection in recipients who receive blood reactive for anti$\mathrm{HBc}$ alone as reported by other researchers ${ }^{41-43}$. There is a compelling existence of $\mathrm{HBV}$ genome in blood donors reactive for only anti-HBc among the other viral markers from previous studies ${ }^{44,45}$. Therefore, screening for HBsAg does not rule out the possibility of HBV transmission, as the donor might be in the window phase, and detection of anti$\mathrm{HBc}$ would serve as a convenient serologic marker during this period ${ }^{46,47}$. In Kenya, testing for HBsAg forms the initial laboratory diagnostic tool applied to confirm HBV infection in potential donors, but it does not give information on previous exposure to $\mathrm{HBV}^{48}$. In the current Kenya blood transfusion service (KBTS) guidelines, anti-HBc is not applied as a screening test for HBV. Therefore, as shown in this study, the safety of blood products and tissue organs should be a major priority in transfusion practice and organ transplants ${ }^{49,50}$. Hepatitis B surface antigen is the only diagnostic marker used in most blood transfusion centres in African countries including Kenya and it does not offer protection against $\mathrm{HBV}$ infection ${ }^{51,17}$.

The current study findings have exhibited a significant association between anti-HBc positivity and some sociodemographic characteristics of the donors. There was a clear association of anti-HBc reactivity with factors such as marital status, type of donor, age and gender of the donors. From the current study people who were single were more likely to have been exposed to HBV as compared to the married or widowed an observation also reported by other authors $^{52}$. Other studies have also reported a significant association between anti-HBc positivity with factors such as gender, age, educational level, intravenous drug use and men having sex with men activity ${ }^{53,54}$. From the current study, most of the positive samples were from individuals aged between 25-45 years of age. According to Alves et al., (2014) they showed that HBV infection was significantly associated with age between 25 and 50 years ${ }^{55}$. Therefore, the current research findings were in agreement with previous studies, which highlighted that middle age was associated with a higher risk of HBV exposure ${ }^{56,57}$. This may be because individuals in this age group are more sexually active and with a lot of risky social behaviours that expose them to HBV infection.

In this study, females were less likely to be anti-HBc positivity. A similar finding was also described by Antar et al., (2010) in Egypt showing that HBV infection was significantly associated with the male gender. ${ }^{58}$ Being male was a factor for HBV exposure as reported in this study and similar finding has also been reported previously in other studies possibly due to high-risk social behaviours the makes them vulnerable to HBV infection ${ }^{59}$. History of using the drug of abuse and hypersexuality infection within this age bracket has been attributed to being male, and especially to those still single ${ }^{60}$. 
In this study, all the anti-HBc reactivity occurred among donors who reported not having involved themselves in risky social behaviour. This is in contradiction with other studies undertaken in southern Brazil in the years 2009 and 2010 pinpointed that tattooing, multiple sex partners, ear piercing

\section{CONCLUSION}

Following evidence of exposure to $\mathrm{HBV}$ infection, there is a significant chance of $\mathrm{HBV}$ transmission irrespective of a donor testing negative for $\mathrm{HBsAg}$, and this is an important message for medical practitioners in deciding whether to transfuse blood or not. The introduction of anti-HBc as a routine screening tool is recommended to all potential blood donors and even in other medical procedures such as dialysis.

\section{REFERENCE}

1. Ocana S, Casas ML, Buhigas I, Lledo JL. Diagnostic strategy for occult hepatitis B virus infection. World J Gastroenterol. 2011. doi:10.3748/wjg.v17.i12.1553

2. Mohamed S, Raimondo A, Pénaranda G, et al. Dried Blood Spot Sampling for Hepatitis B Virus Serology and Molecular Testing. Yu ML, ed. PLoS One. 2013;8(4):e61077. doi:10.1371/journal.pone.0061077

3. Jayaraman S, Chalabi Z, Perel P, Guerriero C, Roberts I. The risk of transfusion-transmitted infections in sub-Saharan Africa. Transfusion. 2010;50(2):433-442. doi:10.1111/j.1537-2995.2009.002402.x

4. Bhawani Y, Raghava Rao P, Sudhakar V. Seroprevalence of transfusion transmissible infections among blood donors in a tertiary care hospital of Andhra Pradesh. Biol Med. 2010;2(4):45-48.

5. Bozorgi SH, Ramezani H, Nooranipour M, et al. Risk factors of viral hepatitis: Yet to explore. Transfus Apher Sci. 2012;47(2):145-149. doi:10.1016/j.transci.2012.06.023

6. Katz LM, Dodd RY. Transfusion-Transmitted Diseases. In: Transfusion Medicine and Hemostasis: Clinical and Laboratory Aspects: Second Edition. ; 2013:453-466. doi:10.1016/B978-0-12-397164-7.00071-9

7. Adejuyigbe EA, Durosinmi MA, Onyia FN, Adeodu OO. Blood transfusion related paediatric HIV/AIDS in Ile-Ife, Nigeria. AIDS Care Psychol Socio-Medical Asp AIDS/HIV. 2003;15(3):329-335. doi:10.1080/0954012031000105388

8. Olotu AA, Oyelese AO, Salawu L, Audu RA, Okwuraiwe AP, Aboderin AO. Occult Hepatitis B virus infection in previously screened, blood donors in Ile-Ife, Nigeria: implications for blood transfusion and stem cell transplantation. Virol J. 2016;13(1):76. doi:10.1186/s12985-0160533-3

9. Weber B. Recent developments in the diagnosis and monitoring of HBV infection and role of the genetic variability of the S gene. Expert Rev Mol Diagn. 2005;5(1):75-91. doi:10.1586/14737159.5.1.75

10. Smith M, , R. Schifman DL. Frequency of false positive IgM antihepatitis B core antibody results M. 2017;63(10):152-172.

11. UN. The Sustainable Development Goals Report. New York; 2019.

12. Zou S, Stramer SL, Dodd RY. Donor Testing and Risk: Current Prevalence, Incidence, and Residual Risk of Transfusion-Transmissible Agents in US Allogeneic Donations. Transfus Med Rev. 2012;26(2):119-128. doi:10.1016/j.tmrv.2011.07.007

13. Schweitzer A, Horn J, Mikolajczyk RT, et al. Estimations of worldwide prevalence of chronic hepatitis B virus infection: a systematic review of data published between 1965 and 2013. Lancet. 2015;6736(15):1-10. doi:10.1016/S0140-6736(15)61412-X

14. Tagny CT, Owusu-Ofori S, Mbanya D, Deneys V. The blood donor in sub-Saharan Africa: a review. Transfus Med. 2010;20(1):1-10. doi:10.1111/j.1365-3148.2009.00958.x

15. Bhattacharya $P$, Chandra PK, Datta $S$, et al. Significant increase in $\mathrm{HBV}, \mathrm{HCV}, \mathrm{HIV}$ and syphilis infections among blood donors in West Bengal, Eastern India 2004-2005: Exploratory screening reveals high frequency of occult HBV infection. World J Gastroenterol. 2007;13(27):3730-3733. doi:10.3748/wjg.v13.i27.3730

16. Tessema B, Yismaw G, Kassu A, et al. Seroprevalence of HIV, HBV, $\mathrm{HCV}$ and syphilis infections among blood donors at Gondar University Teaching Hospital, Northwest Ethiopia: declining trends over a period of five years. BMC Infect Dis. 2010;10(1):111. doi:10.1186/1471-233410-111

17. Japhet M, Adesina O, Donbraye E, Adewumi M. Hepatitis B Core IgM antibody (anti-HBcIgM) among hepatitis B Surface antigen (HBsAg) and use of IDU increase the chance of one getting infected by HBV during adulthood ${ }^{61}$. Other factors that are associated with anti-HBc positivity that we either did not measure, included a history of hepatitis in the family of the donor, visiting barbershops and homosexual behaviour ${ }^{62}$.

Acknowledgement: We would like to give our special thanks to the medical laboratory staff at Aga University hospital (Biochemistry department) for their support during data collection.

\section{Financial Support}

No financial support offered

\section{Conflict of Interest}

The authors declare no conflict of interest related to this study

negative blood donors in Nigeria. Virol J. 2011. doi:10.1186/1743422X-8-513

18. WHO. Global Status Report on Blood Safety and Availability. WHO; 2016.

19. Salawu L, Adegoke AO, Aboderin AO, Huraina HA. Hepatitis B viral markers in surface antigen negative blood donors: the need to look beyond antibody negativity. West Afr J Med. 30(4):292-295.

20. Almutairi HH, Alahmari MM, Al-Zahran BH, et al. Prevalence of serological markers and nucleic acid for blood-borne viral infections in blood donors in Al-Baha, Saudi Arabia. J Infect Dev Ctries. 2016;10(6):619-625. doi:10.3855/jidc.6666

21. Seed CR. Value of retaining HBsAg donor screening where HBV NAT and anti-HBc donor screening apply. ISBT Sci Ser. 2018;13(1):70-75. doi:10.1111/voxs. 12368

22. World Health Organization. Guidelines on Hepatitis B and C Testing.; 2017. doi:10.1007/s00216-014-7926-1

23. Kang S-Y, Kim M-H, Lee W-I. The prevalence of "anti-HBc alone" and HBV DNA detection among anti-HBc alone in Korea. $J$ Med Virol. 2010;82(9):1508-1514. doi:10.1002/jmv.21862

24. Fattahi MR, Safarpour A, Sepehrimanesh M, Hosseini Asl SMK, Mohamaddoust F. The Prevalence of Hepatitis C Virus Infection and Its Related Risk Factors Among the Rural Population of Fars Province, Southern Iran. Hepat Mon. 2015;15(2). doi:10.5812/hepatmon.24734

25. Okalla Ebongue C, Ngouadjeu Dongho E, Texier G, et al. Residual risk of transfusion-transmitted malaria infection in a malaria endemic subSaharan African setting. Transl Med Commun. 2017;2(1):4. doi:10.1186/s41231-017-0013-9

26. Yang H-I, Yuen M-F, Chan HL-Y, et al. Risk estimation for hepatocellular carcinoma in chronic hepatitis B (REACH-B): development and validation of a predictive score. Lancet Oncol. 2011;12(6):568-574. doi:10.1016/S1470-2045(11)70077-8

27. Allain J-P. Occult hepatitis B virus infection: implications in transfusion. Vox Sang. 2004;86(2):83-91. doi:10.1111/j.00429007.2004.00406.x

28. Altunay H, Kosan E, Birinci I, et al. Are isolated anti-HBc blood donors in high risk group? The detection of HBV DNA in isolated anti-HBc cases with nucleic acid amplification test (NAT) based on transcriptionmediated amplification (TMA) and HBV discrimination. Transfus Apher Sci. 2010. doi:10.1016/j.transci.2010.09.012

29. Cochran. Determining Sample Size Degree Of Variability.; 1963.

30. Ednah K. Nyairo, Zipporah Ng'ang'a, James Kimotho, Samoel A. Khamadi, Lihana Raphael, Missiani Ochwoto, Keith Talaam, Joseph Mwangi RL. Mutations in the "a" Determinant Region of Hepatitis B Virus Genotype A among Voluntary Kenyan Blood Donors | Nyairo | Journal of Biology, Agriculture and Healthcare. biology agriculture and healthcare.

https://www.iiste.org/Journals/index.php/JBAH/article/view/31857. Published 2016. Accessed November 18, 2019

31. Weber B, Bayer A, Kirch P, Schlüter V, Schlieper D, Melchior W. Improved detection of hepatitis B virus surface antigen by a new rapid automated assay. J Clin Microbiol. 1999;37(8):2639-2647.

32. Ly KN, Kim AA, Umuro M, et al. Prevalence of hepatitis B Virus infection in Kenya, 2007. Am J Trop Med Hyg. 2016;95(2):348-353. doi:10.4269/ajtmh.16-0059

33. Kisangau EN, Awour A, Juma B, et al. Prevalence of hepatitis B virus infection and uptake of hepatitis B vaccine among healthcare workers, Makueni County, Kenya 2017. J Public Health (Bangkok). October 
2018. doi:10.1093/pubmed/fdy186

34. Salawu L, Huraina HA, Adegoke AO, Aboderin AO. Hepatitis B viral markers in surface antigen negative blood donors: The need to look beyond antibody negativity. West Afr J Med. 2011.

35. El-Zayadi AR, Ibrahim EH, Badran HM, et al. Anti-HBc screening in Egyptian blood donors reduces the risk of hepatitis B virus transmission. Transfus Med. 2008. doi:10.1111/j.1365-3148.2007.00806.x

36. El-Zaatari M, Kazma H, Naboulsi-Majzoub M, et al. Hepatitis B virus DNA in serum of 'anti-HBc only'-positive healthy Lebanese blood donors: significance and possible implications. J Hosp Infect. 2007;66:278-282. doi:10.1016/j.jhin.2007.04.010

37. Said ZN, Sayed MH El, Salama II, et al. Occult hepatitis B virus infection among Egyptian blood donors. World J Hepatol. 2013;5(2):6473. doi: $10.4254 /$ wjh.v5.i2.64

38. V L. Prevalence of hepatitis B virus infection among blood donors with antibodies to hepatitis B core antigen. Int J Med Med Sci. 2012. doi:10.5897/ijmms 12.011

39. Ispub. Hepatitis B Virus And Blood Transfusion Safety In Sub- Saharan Africa. Internet J Infect Dis. 2008;7(2).

40. MacLachlan JH, Locarnini S, Cowie BC. Estimating the global prevalence of hepatitis B. Lancet (London, England). 2015;386(10003):1515-1517. doi:10.1016/S0140-6736(15)61116-3

41. Ogunfemi MK, Olawumi HO, Olokoba AB, et al. Prevalence of antibody to hepatitis B core antigen among hepatitis B surface antigennegative blood donors in Ilorin, Nigeria: A cross-sectional study. Malawi Med J. 2017;29(1):32-36.

42. Bloch EM, Vermeulen M, Murphy E. Blood Transfusion Safety in Africa: A Literature Review of Infectious Disease and Organizational Challenges. Transfus Med Rev. 2012;26(2):164-180. doi:10.1016/j.tmrv.2011.07.006

43. Katchaki JN, Siem TH. Journal of VirologicalMethods, 0. J Virol. 1980;2:119-125.

44. Katsoulidou A, Paraskevis D, Magiorkinis E, et al. Molecular characterization of occult hepatitis B cases in Greek blood donors. $J$ Med Virol. 2009;81(5):815-825. doi:10.1002/jmv.21499

45. Buti M, Rodriguez-Frias F, Jardi R, Esteban R. Hepatitis B virus genome variability and disease progression: The impact of pre-core mutants and HBV genotypes. J Clin Virol. 2005;34(SUPPL. 1). doi:10.1016/S1386-6532(05)80015-0

46. Gerlich WH, Glebe D, Schüttler CG. Hepatitis B viral safety of blood donations: new gaps identified. Ann Blood. 2018;3(0).

47. Al-Sadeq DW, Taleb SA, Zaied RE, et al. Hepatitis B virus molecular epidemiology, host-virus interaction, coinfection, and laboratory diagnosis in the MENA region: An update. Pathogens. 2019;8(2). doi:10.3390/pathogens8020063

48. Dutta A, Odour M, Mwai D. PREVENTING TRANSFUSIONTRANSMISSIBLE INFECTIONS IN KENYA Steps to Increase the Supply of Screened Blood E 2 -improving efficiency and effectiveness for health Blood Screening in Kenya. 2012.

49. Zheng X, Ye X, Zhang L, et al. Characterization of occult hepatitis B virus infection from blood donors in China. J Clin Microbiol. 2011:49(5):1730-1737. doi:10.1128/JCM.00145-11

50. Allain J, Hewitt P, Tedder R, Williamson L. Evidence that anti-HBc but not HBVDNA testing may prevent some HBV transmission by transfusion. Br J Haematol.:186-195.

51. Dodd RY, Stramer SL. Transfusion-Transmitted Infections. Pract Transfus Med. 2013;11(Table 1):132-143. doi:10.1002/9781118520093.ch13

52. Al-Waleedi AA, Khader YS. Prevalence of hepatitis B and C infections and associated factors among blood donors in Aden city, Yemen. East Mediterr Heal J. 2017. doi:10.26719/2012.18.6.624
53. Slot E, Janssen MP, Marijt-van der Kreek T, Zaaijer HL, van de Laar TJ. Two decades of risk factors and transfusion-transmissible infections in Dutch blood donors. Transfusion. 2016;56(1):203-214. doi:10.1111/trf. 13298

54. Felippe D, De G, Machado P, et al. Prevalence and Factors Associated with Hepatitis B Virus Infection Among Senior Citizens in a Southern Brazilian City. 2013. doi:10.5812/hepatmon.7874

55. Alves C, Freitas N, Cunha C. Characterization of the nuclear localization signal of the hepatitis delta virus antigen. Virology. 2008;370(1):12-21. doi:10.1016/j.virol.2007.07.034

56. Jilg W, Hottentrger B, Weinberger K, et al. Prevalence of markers of hepatitis B in the adult German population. J Med Virol. 2001. doi:10.1002/1096-9071(20000201)63:2<96::AID-JMV1002>3.0.CO;2C

57. Qureshi H, Bile KM, Jooma R, Alam SE, Afrid HUR. Prevalence of hepatitis B and C viral infections in Pakistan: findings of a national survey appealing for effective prevention and control measures. East Mediterr Heal J. 2010;16(Supp.):15-23. doi:10.26719/2010.16.supp.15

58. Antar W, El-Shokry MH, Abd El Hamid WA, Helmy MF. Significance of detecting anti-HBc among Egyptian male blood donors negative for HBsAg*. Transfus Med. 2010;20(6):409-413. doi:10.1111/j.13653148.2010.01021.x

59. Hennessey K, Mendoza-Aldana J, Bayutas B, Lorenzo-Mariano KM, Diorditsa S. Hepatitis B control in the World Health Organization's Western Pacific Region: Targets, strategies, status. Vaccine. 2013;31:J85-J92. doi:10.1016/j.vaccine.2012.10.082

60. Nelson NP, Easterbrook PJ, McMahon BJ. Epidemiology of Hepatitis B Virus Infection and Impact of Vaccination on Disease. Clin Liver Dis. 2016. doi:10.1016/j.cld.2016.06.006

61. de Paula Machado DFG, Martins T, Trevisol DJ, et al. Prevalence and factors associated with hepatitis B virus infection among senior citizens in a Southern Brazilian city. Hepat Mon. 2013. doi: 10.5812/hepatmon.7874

62. Huang P. Seroepidemiology of hepatitis B virus infection and impact of vaccination. World J Gastroenterol. 2015;21(25):7842. doi:10.3748/wjg.v21.i25.7842

Peer Reviewed

Competing Interests: None declared

Received: 13 Jun 2019; Accepted: 29 Apr 2020

Cite this article as: Mulakoli F, Gichure M. The prevalence of antibodies to Hepatitis B core antigen among blood donors. E Afr Sci. 2019;1(1):36-44. http://doi.org/10.24248/EASci-D-19-00012.

(C) Mulakoli et al. This is an open-access article distributed under the terms of the Creative Commons Attribution License, which permits unrestricted use, distribution, and reproduction in any medium, provided the original author and source are prop-erly cited. To view a copy of the license, visit http://creativecommons.org/licens- es/by/4.0/. When linking to this article, please use the following permanent link: http://doi.org/10.24248/EASci-D-19-00012. 